\title{
Role of Tetraspanin CD9 Molecule in Fertilization of Mammals
}

\author{
J. JANKOVIČOVÁ ${ }^{\mathbf{1}}$, M. SIMON ${ }^{\mathbf{1}}$, J. ANTALÍKOVÁ ${ }^{\mathbf{1}}$, P. CUPPEROVÁ ${ }^{\mathbf{1}}$, \\ K. MICHALKOVÁ ${ }^{1}$
}

${ }^{1}$ Institute of Animal Biochemistry and Genetics, Slovak Academy of Sciences, Ivanka pri Dunaji, Slovak Republic

Received July 21, 2014

Accepted October 8, 2014

On-line December 22, 2014

\section{Summary}

Fertilization process is a very clever and unique process comprising some essential steps resulting in formation of zygote. Tetraspanin CD9 is considered to be a serious candidate molecule participating in these events. The importance of CD9 has been discussed in relation to acrosome reaction, sperm-binding, sperm-penetration, sperm-egg fusion and eventually, egg activation. The abundant expression of CD9 oocyte plasma membrane and the presence of CD9-containing vesicles in the perivitelline space of intact oocytes have been confirmed. Despite the fact that majority of authors analyzed CD9 expressed on oocytes, several studies considered the function of sperm CD9, too. To understand CD9 involvement, various conditions of in vitro fertilization (IVF) assays using polyclonal as well as monoclonal antibodies or knockout mice were carried out. However, ambiguous data have been obtained about the importance of CD9 in sperm-egg binding or fusion. Although the current findings did not prove any hypothesis, the indispensable role of $C D 9$ in fertilization process was not excluded and the precise role of $\mathrm{CD} 9$ remains unexplained.

\section{Key words}

Tetraspanin • Reproduction • CD antigen • Ova • Spermatozoa

\section{Corresponding author}

J. Jankovičová, Department of Immunogenetics, Institute of Animal Biochemistry and Genetics, Slovak Academy of Sciences, Moyzesova 61, 90028 Ivanka pri Dunaji, Slovak Republic. Fax: +421 24594 3932. E-mail: jana.jankovicova@savba.sk

\section{Introduction}

Fertilization process is a very clever, unique and sometimes also very "tricky" process comprising some essential steps resulting in formation of zygote. Gamete cells passing through the genital tract of both male and female lose some specific structural component to acquire a new one and finish fertilization successfully. Some molecules localized either on gamete cells or in the genital tract tissues involved in particular events of fertilization have been identified.

Although fertilization process has been described in general, the molecules and their exact role are not fully illustrated. Therefore, every molecule found in genital system or on the gamete surface is considered to be a potential candidate molecule involved in this process and significant effort is devoted to characterize and study it closer. A list of molecules known to be present on gametes is very broad and is still enlarging. Molecules known to be involved in mammalian sperm-egg fusion are also reviewed in Klinovska et al. (2014). For a better interpretation of fertilization process complexity, Fard Jahromi and Shamsir (2013) assembled the protein-protein interaction networks of human egg and human sperm. The egg protein map involves 1056 proteins and 1700 interactions between these proteins and sperm map comprises 6450 proteins and 34579 interactions which provide the entire possibilities of molecule functional connection. Some of the most studied molecules are also presented in Table 1. 
Table 1. Some of the molecules detected on gamete surface or in male and female genital tract with potential involvement in fertilization process.

\begin{tabular}{|c|c|c|}
\hline & Molecule & References \\
\hline \multirow[t]{12}{*}{ Male system } & CD46 & $\begin{array}{l}\text { Anderson et al. 1989, Inoue et al. 2003, } \\
\text { Mizuno et al. 2004, Antalíková et al. } 2007\end{array}$ \\
\hline & CD35 (CR1; complement receptor 1) & Anderson et al. 1993 \\
\hline & CD11b/CD18 (R3; complement receptor 3) & Anderson et al. 1993 \\
\hline & CRISP1 (epididymal protein DE) & Da Ros et al. 2008 \\
\hline & CRISP2 & Busso et al. 2007 \\
\hline & calmodulin & Courtot et al. 1994 \\
\hline & IZUMO & Okabe et al. 1987 \\
\hline & CD52 & Hale et al. 1993, Michalková et al. 2010 \\
\hline & CD55 & He et al. 2000 \\
\hline & fertilin $\alpha$, fertilin $\beta$, cyritestin & $\begin{array}{l}\text { Bigler et al. 2000, Blobel 2000, Evans et al. } \\
\text { 1997, Evans et al. 2002, Yuan et al. } 1997\end{array}$ \\
\hline & Crry & Xu et al. 2000 \\
\hline & CD59 & Rooney et al. 1992 \\
\hline \multirow[t]{11}{*}{ Female system } & CD35 & Anderson et al. 1993 \\
\hline & CD46 & Taylor and Johnson 1996 \\
\hline & Integrins $(\alpha 6 \beta 1, \alpha 3 \beta 1, \alpha 5 \beta 1, \alpha v \beta 3)$ & Reviewed in Rubinstein et al. 2006 \\
\hline & CD81 & Ziyyat et al. 2006 \\
\hline & CD151 & Ziyyat et al. 2006 \\
\hline & CD98 & Takahashi et al. 2001 \\
\hline & CD52 & Hasegawa et al. 2008 \\
\hline & CD55 & He et al. 2000 \\
\hline & IgSF8 & Glazar and Evans 2009 \\
\hline & CD59 & Rooney and Morgan 1992 \\
\hline & JUNO & Bianchi et al. 2014 \\
\hline
\end{tabular}

\section{CD9 - a serious candidate molecule for involvement in fertilization process}

CD9 protein belongs to the tetraspanin super family. Beside the CD9, several other differentiation antigens CD37, CD53, CD63, CD81/TAPA-1, CD82 and CD151 (Szala et al. 1990, Jankowski et al. 1994, Takagi et al. 1995) are classified in this family.

Concerning the cell expression, all cells seem to express several tetraspanins, with exceptions of erythrocytes (Boucheix et al. 1985, Shaw 1994, Sincock et al. 1997, Rubinstein and Boucheix 1999, Sincock et al. 1999) and tetraspanins were found in many species (Hemler 2003). Some tetraspanins have a wide distribution, whereas others have very restricted pattern (Boucheix and Rubinstein 2001). On the mammalian oocyte membrane, the tetraspanins CD9, CD81 and
CD151 (Ziyyat et al. 2006), CD63 (Sabetian et al. 2014) in human and CD81, CD98 (Takahashi et al. 2001) in mice have been detected. Chen et al. (1999) observed CD9 localization on the plasma membrane of oocytes in the ovary as well as on oocytes isolated from the oviduct and Ziyyat et al. (2006) and previously Kaji et al. (2000), Le Naour et al. (2000), Miyado et al. (2000) confirmed the abundant expression of CD9 egg plasma membrane in mice.

Tetraspanins are characterized by four transmembrane regions and two extracellular loops (Boucheix et al. 1991). These domains are of unequal size, small extracellular loop (EC1) contains 20-28 amino acids and the large extracellular loop (EC2) contains 76-131 amino acids (Boucheix and Rubinstein 2001), which both can interact with other luminal proteins including potential specific receptors. The 
transmembrane anchor may interact with other transmembrane segments; and the N-terminal and C-terminal cytoplasmic tails may interact with cytoskeletal elements including microfilaments, microtubules and molecules involved in signal transduction processes (Lefévre et al. 2010). Tetraspanins are enriched in cholesterol-rich microdomains of a unique lipid composition distinct from lipids rafts, where they organize other proteins such as integrins, kinases, human leukocyte antigens and growth factor receptors (Hemler 2003, Lazo 2007). These complex associations create tetraspanin webs involved in signaling, cell-cell and cellextracellular matrix adhesion, and in processes as cell migration/motility, viral infection, immune responses, tumor metastasis and hematopoietic stem cell differentiation (Yunta and Lazo 2003). Association and organization of these membrane proteins in different cellular membranes can be regulated through the covalent modification, palmitoylation (Charrin et al. 2002). Palmitoylation of membrane proximal cysteins is required for their association with the cholesterol complexes (Charrin et al. 2003a). Palmitoylated tetraspanins are thought to be important for assembly of webs, favoring association with other members of this superfamily and their associated proteins (Berditchevski et al. 2002, Yang et al. 2002).

It is known that molecular weight of CD9 molecule (approximately $24-25 \mathrm{kDa}$ ) is similar in all tissues and cell types in mice (Ito et al. 2010), pig (Kaewmala et al. 2011) and cattle (Martin-Alonso et al. 1992). Chemical structure, molecular organization and expression pattern designate CD9 molecule for implication in fertilization process. Various conditions of in vitro fertilization (IVF) assays using polyclonal as well as monoclonal antibodies were carried out to resolve this question. The second approach was through the genemanipulated animals, where knockout mice have been usually used. It should be mentioned that achieved results differ largely.

Based on functional role of large extracellular loop (EC2) in many tetraspanins, this part of tetraspanin structure was supposed to be important for fusion (Zhu et al. 2002, Hemler 2003). Actually, Zhu et al. (2002) observed inhibited sperm-egg fusion when oocytes were preincubated with bacterially expressed mouse EC2 construct and demonstrated that constructs including the large extracellular loop of CD9 significantly inhibited gamete fusion only if were incubated with oocytes, but not with sperm. Higginbottom et al. (2003) reported a hypervariable region of CD9 large extracellular domain important for the sperm-egg fusion.

The cytoplasmic tails of tetraspanin molecule can interact with cytoskeletal elements (Lefévre et al. 2010). Sutovsky et al. (1996) found out that disruption of actin microfilaments with microfilament disruptors during bovine or murine fertilization decreased sperm incorporation into the ooplasm whereas fusion and oocyte activation was affected in dependence of used disruptor type. That is the other reason to consider the role of CD9 molecule in reproduction in connection with its association complexity.

\section{CD9, integrins and disintegrins}

Functional role of CD9 protein in fertilization process seems to be dependent on the assembling of tetraspanin web comprising different molecular actors. The group of integrins as well as members of ADAMs family (proteins with a disintegrin and metalloprotease domain) fertilin $\alpha$ (ADAM-1), fertilin $\beta$ (ADAM-2), and cyritestin (ADAM-3), expressed on sperm, were thought to be important for sperm-binding or gamete fusion. With regard to the function in general, the integrin receptors can mediate cell adhesion, migration, proliferation, cell differentiation and apoptosis and connect the intracellular cytoskeleton and extracellular matrix (Schwartz et al. 1995). Due to the observed integrins expression on oocytes, they were studied in IVF assays, although controversial data about the importance for sperm-egg binding or fusion were obtained.

Shaw et al. (1995), Jones et al. (1996) and Hemler (1998) described interaction of tetraspanin CD9 protein with the integrins $\alpha 3 \beta 1, \alpha 6 \beta 1, \alpha 4 \beta 1$ and $\alpha \operatorname{IIb} \beta 3$ where CD9 mediates migration, signaling and adhesion to extracellular matrix substrates. Chen et al. (1999) reported an interaction between sperm fertilin $\beta$ and $\alpha 6 \beta 1$ bound to egg cytoskeleton, which can be possibly mediated by CD9. Although $\beta 1$ integrins are the major molecules identified in tetraspanin macromolecular complexes (Lozahic et al. 2000, Yauch et al. 2000), the interaction of CD9 with integrins seems to be indirect (through another tetraspanin) (Yauch et al. 1998, Serru et al. 1999). These suggestions were confirmed in co-localization experiments, where CD9 was not identified in complex with $\alpha 6$ which supports the hypothesis of indirect association of CD9 with $\alpha 6 \beta 1$ (Berditchevski et al. 2002, Charrin et al. 2003b, Ziyyat 
et al. 2006). Miller et al. (2000) found out that the lack of $\alpha 6 \beta 1$ integrin in total $\alpha 6$-integrin knockout mice has not affected oogenesis and maturation of eggs from ovaries cultivated in vitro. Moreover, no reduction in number of sperm bound or fused with eggs lacking $\alpha 6$ has been observed compared to wild type control.

Regarding the ADAMs family, fertilin $\alpha$ and $\beta$ accrue from larger precursors at different stages of sperm maturation in the testes and epididymis (Blobel 2000). The fertilin $\beta$ is present on the equatorial region of mouse sperm (Yuan et al. 1997) and in posterior head region of guinea pig sperm (Blobel 2000). The extracellular domain of fertilin $\alpha$ and fertilin $\beta$ binds to microvillar region on mouse oocytes (Evans et al. 1997, Bigler et al. 2000). Cyritestin molecule expression has been found out to be restricted in testes (Evans 2002).

Chen et al. (1999) proved binding inhibition of fertilin-coated beads (and sperm) to eggs by monoclonal anti-CD9 antibody and suggested two possible models for explanation. In the first model, fertilin may contact integrin $\alpha 6 \beta 1$ or parts of CD9 and consequently monoclonal antibody either sterically blocks fertilin binding or causes dissociation between $\alpha 6 \beta 1$ and cytoskeleton and inhibits fertilin binding. In the second model Chen et al. (1999) suggest, CD9 is not physically associated with $\alpha 6 \beta 1$ and binding of monoclonal antibody to CD9 sends a signal into egg that weakens the association of $\alpha 6 \beta 1$ with cytoskeleton (thereby inhibiting fertilin binding). The same authors observed apical epithelial expression of CD9 on mouse tissues and $\alpha 6$ subunit in the utero-tubal junction and oviductal isthmus correlated with requirement of sperm to adhere to these sites and with the failure of fertilin $\beta$-lacking sperm to transit these regions. Sperm-egg fusion and binding were reduced in $\mathrm{mAb}$ CD9-pretreated zona-free eggs and fertilin $\beta^{-/-}$eggs. Interestingly, Chen et al. (1999) showed that anti-CD9 antibodies influenced not only the sperm-egg binding and fusion, but also the binding of the fertilin $\beta$ and cyritestin (Takahashi et al. 2001) disintegrin domain to the egg. Possibly, CD9regulation of ADAM- integrin association should be taken into consideration. Moreover, they studied involvement of the fertilin $\beta, \mathrm{CD} 9$, and $\alpha 6 \beta 1$ in a model of murine sperm migration. They supposed that sperm come to the epithelium and the affinity between sperm fertilin $\beta$ and oviductal integrin $\alpha 6 \beta 1$, associated with CD9, is changed according to activation. Integrins can exist with low or high binding capacity for particular ligands and CD9 possibly influence the activation state of integrin (Xiang et al. 2002). Integrins, CD9 and fertilin are distributed in a way that indicate their participation in mediation the binucleate cell migration, adhesion, and/or fusion with uterine epithelium, processes connected with ruminant placentation (Xiang et al. 2002).

In spite of the gamete localization and different experimental studies performed, an essential role of mentioned integral membrane proteins in fusion has not been finally confirmed.

\section{Reproduction process in CD9-deficient mice}

Several authors (Kaji et al. 2000, Le Naour et al. 2000, Miyado et al. 2000) published studies where CD9-deleted mice were undertaken in experiments. Females exhibited normal oogenesis in comparison with the wild type mice, but many sperm "prisoned" in perivitelline space were detected due to the failure of fusion ova plasma membrane (Kaji et al. 2000, Miyado et al. 2000). Inoue et al. (2007) tested various genemanipulated animals and observed normal zonapenetration when CD9-deficient ova have been used, but due to a lack of fusion, spermatozoa accumulated in the perivitelline space as there was no zona pellucidabased antipolyspermy defense facilitated. In the study of Miyado et al. (2000), $\mathrm{CD}^{-} \%$ females were infertile whereas $\mathrm{CD}^{-} \%$ males showed normal fertility when mated with wild type mice. The same authors observed failure of fusion and consequently decrease in a litter size in $\mathrm{CD}^{-/}$mouse females to less than $2 \%$ compared to wild type mice. On the other hand, fertilized eggs developed to term, when sperm were directly injected into oocytes. Kaji et al. (2002) showed that incompetence of sperm-egg fusion in CD9-deleted mice (despite normal binding and penetration through zona pellucida) can be rendered by mouse mRNA CD9 injection into these oocytes. Taken all together, CD9 seems to be directly involved in the events of sperm and egg membrane fusion, although, experiments using the knockout mice are very relevant for functional study of CD9 molecule but as all approaches, some limitations should be taken into account. If the results from IVF assays using knockout mice are evaluated, some differences in CD9-deficient eggs compared to wild type mouse eggs should be considered. Jégou et al. (2011) described changes in microvilli properties as well as in protein expression and distribution. 


\section{Study of CD9 in fertilization process by monoclonal antibodies}

CD9 role can be also studied by additional approach, in experimental assay using monoclonal antibodies (mAbs) directed to CD9 or integrin molecules and valuable data can be achieved regarding the importance of various epitopes in particular steps of fertilization process. In agreement with Chen et al. (1999) and Takahashi et al. (2001) who showed that antibodies against CD9 blocked sperm-egg binding and fusion in mice, Zhou et al. (2009) observed a decrease in number of bound sperm as well as penetrated eggs in IVF assay in cattle. On the contrary, Miyado et al. (2000) pre-treated mouse zona pellucida-free eggs with anti-CD9 antibody, no effect on rate of sperm-binding to eggs has been determined. However, when the insemination time was shortened from 60 to $15 \mathrm{~min}$, reduction of sperm-binding to $53 \%$ has been detected. Regardless the valuable results, these cases point out also to an importance of experimental condition settings for consistent outstanding achievement. When Miller et al. (2000) assessed fertilization rate in wild cumulus-intact type eggs, it was nearly completely inhibited using anti-CD9 antibody (KMC8.8) but not anti- $\alpha 6$ antibody (GoH3). The antibody did not affect passage of sperm through zona pellucida and cumular mass. As we mentioned previously, it seems CD9 acts independently to $\alpha 6 \beta 1$ integrin but probably in association with other molecules. On the contrary, Almeida et al. (1995) observed inhibition in sperm-binding to zona-free eggs by $\mathrm{GoH} 3$. These findings are in agreement with conclusion of Evans et al. (1997) who described dependence of antibody effect on oocytes preparation. The results can be influenced by methods of zona pellucida removal or whether zona pellucida-intact eggs were applied. Particularly, pronase treatment but not chymotrypsin or acid Tyrode eliminated CD9 from the membrane and caused infertility of eggs (Komorowski et al. 2003).

\section{CD9 as a part of membranous vesicles}

Production and acceptance of membranous vesicles derived from different cells is thought to be a mechanism ensuring communication between cells (Thery et al. 2009).

Epididymosomes are referred to as a membranous vesicles secreted by cells into intraluminal fluid of epididymis. Fertilizing ability acquirement of spermatozoa is associated with transit through the epididymal caput and corpus and epididymosomes are responsible for protein transfer and modification of sperm membrane composition (Sullivan et al. 2007). Wubbolts et al. (2003) and Trajkovic et al. (2008) described CD9 as a component of membrane vesicles released from a wide range of cells. Miyado et al. (2008) incubated the CD9-deleted mouse epididymal spermatozoa ( $\mathrm{CD}^{-/}$) with $\mathrm{CD}^{-} /$zona pellucida-removed eggs in medium containing the vesicles from $\mathrm{CD}^{+} /^{+}$eggs. Consequently, the spermatozoa were capable of fusion with $\mathrm{CD}^{-} /$eggs that indicate rendering of fusibility $\mathrm{CD}^{-} /$eggs. The same authors showed localization of CD9-containing vesicles in the perivitelline space and their accumulation here during the germinal vesicle and metaphase II-arrested stages of oocytes. Moreover, CD9 deficiency led not only to impaired microvilli formation on ooplasm (microvilli improve anchor of penetrating spermatozoa) (Runge et al. 2007), but also decreased accumulation of vesicles in perivitelline space. Miyado et al. (2008) found out that anti-CD9 antibody inhibited the association of sperm with CD9-containing vesicles as well as sperm-egg fusion. Interestingly, Kaji et al. (2000) observed CD9 distribution over the entire oocyte surface except the region overlying the mitotic spindle, which is the only area lacking the microvilli on the oocyte surface and where sperm inefficiently fuse with oocytes. Zhu et al. (2002) observed CD9 absent region over the metaphase plate and CD9 expression has been identical to microvilli expression in mouse oocytes. However, Li et al. (2004) detected no CD9-deficient area when porcine oocytes were tested. Differences in CD9 distribution between mouse and pig oocytes were the same as cortical granule (CG) distribution. There is not CG-free domain in mature porcine oocytes (Wang et al. 1997). After co-incubation, Kaji et al. (2000) demonstrated, that hamster egg $\left(\mathrm{CD}^{+/+}\right.$) facilitates the fusion of sperm with $\mathrm{CD}^{-/}$eggs which indicates a mechanism, similar with mouse, through egg-released material-vesiculosomes. On the contrary, Gupta et al. (2009) and Barraud-Lange et al. (2012) obtained completely different data in similar experiments in mice. Former detected only $1.5 \%$ fusion of CD9-deficient oocytes in three experiments where CD9-lacking oocytes were inseminated in the presence of wild type oocytes. On the other hand, Barraud-Lange et al. (2007) have observed staining of anti-CD9 antibody on the head of $\mathrm{CD}^{-} /$males sperm in perivitelline space after IVF assay. These results support the hypothesis that transfer of oocyte membrane fragments containing CD9 
on sperm has occurred. This suggestion was also confirmed in experiments, where no transfer of fluorescent dye between oocytes has been detected, but $10 \%$ of recovered spermatozoa showed oocyte-bound stain particles (represented oocyte plasma membrane fragments). Barraud-Lange et al. (2012) observed that fertilization ability of $\mathrm{CD}^{-/}$mouse eggs cannot be reconstituted by sperm with surface bound CD9 oocyte membrane fragments.

\section{CD9 on spermatozoa}

For the first time, CD9 was detected in mouse and rat spermatogonia (Kanatsu-Shinohara et al. 2004, Kierszenbaum et al. 2006). An appearance of CD9 during the spermatogenesis and its expression on sperm was reported by Ito et al. (2010) in mice. Presence of CD9 mRNA has been detected on developing germ cells up to round spermatids and CD9 protein was found in primary spermatocytes up to nearly secondary spermatocytes but later the signal was getting weak or completely lost and again appeared in elongated spermatids. Generally, the signal was detected in spermatogonia, spermatocytes and round spermatids in all stages and no positive signal in Sertoli cells and in elongating and elongated spermatids. In electron microscopy of acrosome-reacted mouse spermatozoa using anti-CD9 antibody, immunogold particles have been predominantly concerned on the inner acrosomal membrane but many gold particles were found on the released vesicles (formed by fusion of plasma and outer acrosomal membrane) and on the surface of the equatorial segment (Ito et al. 2010). Barraud-Launge et al. (2012) observed the presence of CD9 molecule on $10 \%$ of cauda epididymal mature sperm and on $60-75 \%$ of acrosome-reacted murine sperm.

\section{CD9 in non-rodent species}

Only poor information is available in relation to CD9 in man and non-rodent species of animals. As for human reproduction, CD9 has been found in germinal vesicle oocytes as well as metaphase I and metaphase II oocytes (Coskun et al. 2003, Ziyyat et al. 2006). Recently, Salvolini et al. (2013) described lower expression of CD9 in asthenozoospermic human sperm compared to normospermic samples.

For the first time, porcine CD9 molecule localization on gametes has been determined by Li et al. (2004). CD9 was observed after immunohistochemical staining on granulosa cell membrane as well as on oocyte plasma membrane in preantral follicles and in the fully grown follicles. Moreover, the immunofluorescence signal detected on the membrane of oocytes was enhanced as nuclear stage proceeded from germinal vesicle through metaphase I to metaphase II. Consistently, the density of $24 \mathrm{kDa}$ protein representing CD9 oocyte molecule detected in immunoblotting, significantly increased during oocyte maturation. Porcine sperm was also subjected to immunofluorescence assay but no positive signal was observed. Both, sperm-binding and sperm-oocyte fusion were significantly reduced in the ZP-free oocytes, when the oocytes were pre-incubated with anti-CD9 antibody (Li et al. 2004). Based on results in mice, similar system involved in fertilization process could be assumed. Only one study concerning the expression of CD9 in reproductive and non-reproductive tissues in porcine is available (Kaewmala et al. 2011). The semi-quantitative reverse transcription PCR showed CD9 expression in Leidig cells, Sertoli cells and germ cells within the testis, in the epithelial cells of epididymis, vas deferens, prostate gland and spermatozoa in the lumen of epididymis. Moreover, using the immunofluorescence assay, Kaewmala et al. (2011) detected CD9 in the acrosomal region and acrosomal membrane of epididymal spermatozoa although Li et al. (2004) have not been previously successful. Kaewmala et al. (2011) used spermatozoa from the different regions of reproductive boar tract whereas Li et al. (2004) treated ejaculated frozen-thawed spermatozoa what was considered as the reason of this discrepancy.

In 2009, presence of CD9 on plasma membrane of matured bovine oocytes specifically has been confirmed (Zhou et al. 2009). In IVF assay where CD9 on oocytes was blocked by anti-CD9 antibody (IVA-50), significant reduction in either sperm bound to oocytes or penetrated spermatozoa was denoted. Recent study of Cupperová et al. (2014) detected CD9 expression on bull spermatozoa and described the distribution within the whole male genital tract. Regarding the tissue expression, the bovine CD9 was expressed constitutively on the apical surface of uterine epithelium, consistently to human uterine epithelium (Park et al. 2000, Yanez-Mo et al. 2001). Chen et al. (1999) were not able to detect murine CD9 in the uterine epithelium but CD9 was expressed on the apical surface of the uterine-oviduct junction. However, the group of Xiang et al. (2002) detected CD9 presence in subpopulation of binucleate cells in bovine trophoblast and they speculated that this 
surface expression of CD9 can be a prerequisite for their migration. Recently, Caballero et al. (2013) examined the particular parts of bovine epididymis for $\mathrm{CD} 9$ presence. They observed vesicles expressing CD9 predominantly in the epididymal fluid, gained from cauda region, whereas epithelial cells of epididymis, caput, corpus and cauda were positive for CD9. Based on proteomic analysis, Girouard et al. (2011) confirmed CD9 association with cauda epididymosomes. According to Caballero et al. (2013), CD9-positive microvesicles (30-120 nm) took about one third of total vesicle protein amount in epididymal fluid and only microvesicles secreted from the corpus distal to the cauda regions were CD9-positive. Moreover, transfer of CD9 molecules from membranous vesicles to acrosome and midpiece of epididymal spermatozoa has been detected. However, transfer of CD9 to epididymal corpus distal spermatozoa decreased only moderately (10-15\%) when CD9 has been blocked by specific antibodies. Therefore, CD9 involvement in tetraspanin web on sperm membrane should be considered rather than $\mathrm{CD} 9$ molecule can act itself.

\section{What is the role of $\mathrm{CD} 9$ in reproduction?}

In terms of fertilization process, the particular mechanisms of the most acting "players" are only assumptive and there are only few molecules which function is fully understood. Although a great deal of information and experimental data are available regarding CD9, significant effort is permanently devoted to solve the precise function of this protein at fertilization. Majority of authors assigned CD9 expressed on oocytes but several studies identified CD9 on sperm, too. In general, as Stein et al. (2004) suggested, the role of CD9 should be considered in interaction with other/s molecules on oolema ("in cis") in egg-spermatozoa fusion and furthermore, CD9 could act as a receptor for sperm ("in trans") due to its association with integrins. It is therefore possible; that CD9 is involved in fertilization process not only through the expression on oocytes but an additional function in transfer of egg membrane vesicles to spermatozoa has been proposed by several reports. Rubinstein et al. (2006) and consequently, BarraudLange et al. (2007) and Miyado et al. (2008) found out that spermatozoa acquire CD9 from oocyte membrane in a process similar to trogocytosis, shortly described as a cell to cell contact-dependent transfer of membrane fragments. CD9 is transferred from oocyte membrane to the spermatozoa in the perivitelline space. According to
Barraud-Lange et al. (2007), before the fusion, the sperm membrane reorganization comprising transfer of egg membrane fragments containing CD9 on sperm is needed. The possibility that oocytes themselves induced sperm CD9 expression was excluded as murine sperm from CD9-deficient males were applied in these experiments. In 2008 Myiado et al. published that CD9-containing vesicles (able to facilitate sperm-egg fusion) are released from eggs before fertilization in hamster and mice. Zuccotti et al. (1991) observed fluorescent stain transfer appertained to egg membrane CD9 from growing oocytes to binding sperm. Later when Miyado et al. (2000) examined oocytes in the same stage, CD9 presence on cell membrane but absence of CD9-containing vesicles has been observed. These authors supposed that cell membrane CD9 is responsible for transfer of fluorescent signal.

Recently, Barraud-Lange et al. (2012) examined mouse eggs for ability to pass the membrane material to sperm via trogocytosis and exosome and both pathways have been confirmed to coexist. However, only low portion $(<10 \%)$ of sperm positive for transferred membrane fragments or captured vesicles have been detected. Moreover, despite of no fertilization observed in CD9-null mouse oocytes, trogocytosis and vesicle transfer were not disturbed and loss of CD9 did not change the synthesis and secretion of vesicles localized in perivitelline space of CD9-deficient oocytes. Therefore the hypothesis of CD9 dependency of gamete exchange has been excluded. Ito et al. (2010) detected CD9 being unmasked after the acrosome-reaction in mice spermatozoa but no significant role in fertilization was concluded in $\mathrm{CD}^{-} /$male mice; fertilizing ability was not influenced when pregnancy rates or a litter size was compared. In the study of Barraud-Lange et al. (2012), exosome exchange and trogocytosis of membrane material from egg plasma membrane occurs predominantly on acrosome-reacted sperm.

Based on achieved results, in spite of large discrepancies, several hypotheses about possible mechanisms of CD9 functioning could be formulated. CD9 on the inner acrosomal membrane is relocated to the equatorial region of sperm head and can associate with the environment around the vesicles (originated from fusion of plasma and outer acrosomal membrane). Sperm CD9 on the inner acrosomal membrane can act as an organizer for the other inner acrosomal membrane proteins due to tetraspanin character of $\mathrm{CD} 9$ (Ito et al. 2010). CD9 can play a role in secondary attachment of 
sperm to the zona pellucida. After acrosome reaction, fusion of plasma membrane and outer acrosomal membrane occurs and inner acrosomal membrane receptors are exhibited (Ito et al. 2010). During the fusion, CD9 released from the oocyte surface could attach the sperm surface (Miyado et al. 2008). It can be speculated that CD9 can act as a binding molecule on sperm inner acrosomal membrane or after transfer also on plasma membrane. Subsequently, CD9 could facilitate the fusion by the interaction between egg and sperm CD9 molecules. Sutovsky (2009) suggested IZUMO protein could be a binding ligand acquiring CD9 from the oocytereleased vesicles and further triggering fusion by interaction with CD9 on oolema. CD9 can act as a linker between the molecules involved in sperm binding or molecules facilitating fusion as Kaji and Kudo (2004) early considered. These hypotheses are supported by Vicens and Roldan (2014), they found correlated evolution between extracellular domain of IZUMO1 and CD9, suggesting that these proteins could undergo some form of specific molecular interaction.

Recently, the first essential receptor couple, the sperm IZUMO1 and the egg Juno (folate receptor 4), involved in fertilization process of mammals has been identified (Bianchi et al. 2014). According Chalbi et al. (2014), along with IZUMO1, egg CD9 concomitantly accumulates in the adhesion area. Based on these findings, CD9 as a partner of Juno in adhesion-induced membrane organization before the fusion has been suggested.

The tetraspanin nature of CD9 molecule must not to be omitted when potential role of CD9 in fertilization process is taken into consideration. Expression of CD9 in microvillar area of oocyte indicates its involvement in fertilization through the interaction with integrin and consequently disintegrin molecules. In general, integrins pose the junction between extracellular matrix and cytoskeleton and integrins expressed on egg. Miyado et al. (2000) proved physical association of integrin $\alpha 6 \beta 1$ with CD9 on mouse egg membrane by co-immunoprecipitation using $\alpha 6$ antibody. The same authors suggested that integrin $\alpha 6 \beta 1$ may transduce signal to CD9 and initiate or otherwise promote fusion. Takahasi et al. (2001) presumed that egg surface tetraspanin web involving $\beta 1$-integrin-associated proteins including CD9 may constitute and save a site for fusing sperm. In study of Ziyyat et al. (2006), CD9 mAb prevented $\alpha 6 \beta 1$ integrin clustering and sperm-egg fusion when added solely before zona pellucida removement in human IVF assay. CD9 can be responsible for reorganization of some membrane proteins including $\alpha 6 \beta 1$ integrin. Glazar and Evans (2009) observed the inhibition of sperm-binding to anti-CD9-blocked eggs only up to $60 \mathrm{~min}$ after insemination. They proposed the role of CD9 at the beginning of sperm-egg contact as CD9 increases adhesion. Possibly, via interaction of CD9 with adhesion molecules, CD9 can participate in egg activation process. Jégou et al. (2011) studied CD9 function in fertilization process using force measurement technique and different types of adhesion interaction between gametes were distinguished. Although, CD9-deficient eggs showed reduced fusion rate, number of bound sperm was increased compared to wild type mice probably due to increase of accessible sperm adhesion sites. It is important to note that disappearance of strong type adhesion interaction has been revealed and the authors suggested CD9 function directly in the adhesion site on sperm and egg membrane before the fusion occurs and consequently successful fusion is a direct consequence of CD9 controlled adhesion properties. According to Higginbottom et al. (2003), it is likely that CD9 interacts with different egg proteins, involved in sperm binding or fusion, respectively, and brings them together into close proximity. Similar mechanism for the other tetraspanins has been reported in virus-induced cell-cell fusion by Loffler et al. (1997).

The ability of tetraspanins to create molecular complexes between each other and other membrane proteins is crucial for their functionality. Boucheix and Rubinstein (2001) and Hemler (2003) differentiated particular primary complexes (tetraspanin and one partner molecule) according to the solubility in various detergents and using cross-linking experiments. Therefore, for better elucidation of CD9 function, other web-associating molecules should be also mentioned. In CD9 positive vesicle population isolated from bovine epididymis, three proteins were represented mostly, P25b, GliPr1L1 and MIF whereas all of them are involved in sperm function as described Parent et al. (1999), Frenette et al. (2003), Eikhoff et al. (2004), Caballero et al. (2012). When tetraspanin-enriched microdomains involved in mechanism of molecular transfer regarding CD9 molecule have been analyzed, CD26 and CD224 were found to be associated with CD9-positive microvesicles isolated from bovine epididymis in the tetraspanin web. Moreover, CD26 synergic effect with CD9 was observed in the experiments where transfer of molecules from microvesicles to epididymal sperm has 
been examined. The study of Glazar and Evans (2009) demonstrated from co-immunoprecipitation experiments that CD9 and IgSF8 are in the first-level interaction in mouse egg and described interaction of CD9 with IgSF8 in a primary cell type for the first time. CD9 could have a major role in mouse fertilization through the association with other membrane proteins on egg membrane within the tetraspanin web, potentially also as IgFS8.

CD81 is a tetraspanin that associates with several $\beta 1$ integrins and also with CD9 molecule (Hemler 1998). Although CD81 shares homologous transmembrane domains with CD9 and similar biological function, different subcellular oocyte localization has been observed (Horváth et al. 1998). CD81 was predominantly localized in the zona-pellucida whereas CD9 in perivitelline space. Both proteins were found to be a part of oocyte exosomes (Ohnami et al. 2012). In IVF assay, anti-CD81 antibody caused moderate inhibition of sperm-egg binding and weak influence on fusion as referred Takahashi et al. (2001). On the other hand, microinjection experiments in study of Ohnami et al. (2012) showed that force expression of CD9 can improve the fusion rate decreased due to CD81deficiency in oocytes. Reverse ability of CD 81 has not been achieved. Therefore the conductive role of CD81 to the oocyte CD9 in the sperm-egg fusion has been suggested. Eventually, CD81 can be involved in CD9 transfer to sperm membrane. Another differentiation antigen CD151 links $\alpha 3 \beta 1$ and $\alpha 6 \beta 1$ integrin to other tetraspanins, including CD9 (Ito et al. 2003, Charrin et al. 2003b). Rubinstein et al. (1996) found out that CD9 as well as CD63, CD81 and CD82 organize a complex with other associated molecules as the VLA integrins and HLA-DR antigens. Recently, interactions between CD9 and CD49B, CD63 and IZUMO1 during human fertilization were predicted using several computational approaches (Sabetian et al. 2014). Some authors (Ellerman et al. 2003) concluded CD9 as a receptor for PSG17 (a member of pregnancy-specific glycoprotein family), which, similar to IZUMO, is a member of the immunoglobulin superfamily. CD9-deficient eggs were unable to bind PSG17 molecule and moreover, sperm-egg fusion was blocked when the egg PSG17 binding site was mutated or not available. They suggested possible CD9 function in sperm-egg fusion through the binding the sperm PSG17.

\section{Conclusion}

The involvement of CD9 in fertilization process is likely to be related to tetraspanin character of this molecule. Belonging to this protein superfamily predicts this protein to bind other molecules in tetraspanin web complex, comprising large spectrum of potential associating partners. In all presented studies, some discrepancies in achieved results were obvious, mainly due to various experimental designs and the role of CD9 has been discussed in relation to all events of fertilization process: acrosome reaction, sperm-binding, spermpenetration, sperm-egg fusion and eventually, in egg activation. Summarizing, although these findings did not prove any hypothesis, the indispensable role of CD9 in fertilization process was not excluded and the precise role of $\mathrm{CD} 9$ remains unexplained.

\section{Conflict of Interest}

There is no conflict of interest.

\section{Acknowledgements}

This work was supported by grants VEGA 2/0006/12 and APVV/0137/10.

\section{References}

ALMEIDA EA, HUOVILA AP, SUTHERLAND AE, STEPHENS LE, CALARGCO PG, SHAW LM, MERCURIO AM, SONNENBERG A, PRIMAKOFF P, MYLES DG, WHITE JM: Mouse egg integrin alpha 6 beta 1 functions as a sperm receptor. Cell 81: 1095-1104, 1995.

ANDERSON DJ, MICHALSON JS, JOHNSON PM: Trophoblast/leucocyte common antigen is expressed by human testicular germ cells and appears on the surface of acrosome-reacted sperm. Biol Reprod 41: 285-293, 1989.

ANDERSON DJ, ABBOTT AF, JACK RM: The role of complement component C3b and its receptors in sperm-oocyte interaction. Procl Natl Acad Sci USA 90: 10051-10055, 1993.

ANTALÍKOVÁ J, SIMON M, JANKOVICOVÁ J, HOROVSKÁ L: Identification of MCP/CD46 analogue on bovine erythrocytes using the new monoclonal antibody IVA-520. Vet Immunol Immunopathol 115: 155-159, 2007. 
BARRAUD-LANGE V, NAUD-BARRIANT N, BOMSEL M, WOLF JP, ZIYYAT A: Transfer of oocyte membrane fragments to fertilizing spermatozoa. FASEB $J$ 21: 3446-3449, 2007.

BARRAUD-LANGE V, CHALAS BOISSONNAS C, SERRES C, AUER J, SCHMITT A, LEFÉVRE B, WOLF JP, ZIYYAT A: Membrane transfer from oocyte to sperm occurs in two CD9-independt ways that do not supply the fertilizing ability of CD9- deleted oocytes. Reprod 144: 53-66, 2012.

BERDITCHEVSKI F, ODINTSOVA E, SAWADA S, GILBERT E: Expression of the palmitoylation-deficient CD151 weakens the association of alpha 3 beta 1 integrin with the tetraspanin-enriched microdomains and affects integrin-dependent signaling. J Biol Chem 277: 36991-37000, 2002.

BIANCHI E, DOE B, GOULDING D, WRIGHT GJ: Juno is the egg Izumo receptor and is essential for mammalian fertilization. Nature 508: 483-487, 2014.

BIGLER D, TAKAHASHI Y, CHEN MS, ALMEIDA EA, OSBOURNE L, WHITE JM: Sequence-specific interaction between the disintegrin domain of mouse ADAM2 (fertilin beta) and murine eggs. Role of the alpha(6) integrin subunit. J Virol Chem 275: 11576-11584, 2000.

BLOBEL CP: Functional processing of fertilin: evidence for a critical role of proteolysis in sperm maturation and activation. Reprod 5: 75-83, 2000.

BOUCHEIX C, RUBINSTEIN E: Tetraspanins: a review. Cell Mol Life Sci 58: 1189-1205, 2001.

BOUCHEIX C, PERROT JY, MIRSHAHI M, GIANNONI F, BILLARD M, BERNADOU A, ROSENFELD C: A new set of monoclonal antibodies against acute lymphoblastic leukemia. Leuk Res 9: 597-604, 1985.

BOUCHEIX C, BENOIT P, FRACHET P, BILLARD M, WORTHINGTON RE, GAGNON J, UZNAN G: Molecular cloning of the CD9 antigen. A new family of cell surface proteins. J Biol Chem 266: 117-122, 1991.

BUSSO D, GOLDEWEIC NM, HAYASHI M, KASAHARA M, CUASNICU PS: Evidence for the involvement of testicular protein CRISP2 in mouse sperm-egg fusion. Biol Reprod 76: 701-708, 2007.

CABALLERO J, FRENETTE G, D'AMOURS O, BELLEANNÉE C, LACROIX-PEPIN N, ROBERT C, SULLIVAN R: Bovine sperm raft membrane associated Glioma Pathogenesis-Related 1-like protein 1 (GliPr1L1) is modified during the epididymal transit and is potentially involved in sperm binding to the zona pellucida. J Cell Physiol 227: 3876-3886, 2012.

CABALLERO JN, FRENETTE G, BELLEANNÉE C, SULLIVAN R: CD9-positive microvesicles mediate the transfer of molecules to bovine spermatozoa during epididymal maturation. PLOS ONE 8: e6534, 2013.

CHALBI M, BARRAUD-LANGE V, RAVAUX B, HOWAN K, RODRIGUEZ N, SOULE P, NDZOUDI A, BOUCHEIX C, RUBINSTEIN E, WOLF JP, ZIYYAT A, PEREZ E, PINCET F, GOURIER C: Binding of sperm protein IZUMO1 and its egg receptor Juno drives Cd9 accumulation in the intercellular contact area prior to fusion during mammalian fertilization. Development 141: 3732-3739, 2014.

CHARRIN S, MANIE S, OUALID M, BILLARD M, BOUCHEIX C, RUBINSTEIN E: Differential stability of tetraspanin/tetraspanin interactions: role of palmitoylation. FEBS Lett 516: 139-144, 2002.

CHARRIN S, MANIE S, THIELE C, BILLARD M, GERLIER D, BOUCHEIX C, RUBINSTEIN E: A physical and functional link between cholesterol and tetraspanins. Eur J Immunol 33: 2479-2489, 2003a.

CHARRIN S, MANIE S, BILLARD M, ASHMAN L, GERLIER D, BOUCHEIX C, RUBINSTEIN E: Multiple levels of interactions within the tetraspanin web. Biochem Biophys Res Comm 304: 107-112, $2003 \mathrm{~b}$.

CHEN MS, TUNG KSK, COONROD SA, TAKAHASHI Y, BIGLER D, CHANG A, YAMASHITA Y, KINCADE PW, HERR JC, WHITE JM: Role of the integrin-associated protein CD9 in binding between sperm ADAM2 and the egg integrin $\alpha 6 \beta 1$ : implications for murine fertilization. Procl Natl Sci 99: 11830-11835, 1999.

COSKUN S, ELNOUR A, HELLANI A, GAAFAR T: CD9 is expressed on human oocytes. Fertil Steril 80: 268, 2003.

COURTOT AM, FEINBERG JM, SHOEVAERT DA, RAINTEAU DP, WEINMAN SJ: Calmodulin during human sperm incorporation into hamster oocyte: an immunogold electron microscope study. Mol Reprod Dev 38: 170-177, 1994.

CUPPEROVÁ P, SIMON M, ANTALÍKOVÁ J, MICHALKOVÁ K, HOROVSKÁ L', HLUCHÝ S: Distribution of tetraspanin family protein CD9 in bull reproductive system. Czech J Anim Sci 59: 134-139, 2014.

DA ROS VG, MALDERA JA, WILLIS WD, COHEN DJ, GOULDING EH, GELMAN DM, RUBINSTEIN M, EDDY EM, CUASNICU PS: Impaired sperm fertilizing ability in mice lacking Cysteine-Rich Secretory Protein 1 (CRISP1). Dev Biol 320: 12-18, 2008. 
EIKHOFF R, BALDAUF C, KOYRO HW, WENNEMUTH G, SUGA Y, SEITZ J, HENKEL R, MEINHARDT A: Influence of macrophage migration inhibitory factor (MIF) on the zinc content and redox state of protein-bund suphydryl groups in rat sperm: indications for a new role of MIF in sperm maturation. Mol Hum Reprod 10: 605-611, 2004

ELLERMAN DA, HA C, PRIMAKOFF P, MYLES DG, DVEKSLER GS: Direct binding of the ligand PSG17 to CD9 requires a CD9 site essential for sperm-egg fusion. Mol Biol Cell 14: 5098-5103, 2003.

EVANS JP: The molecular basis of sperm-oocyte membrane interactions during mammalian fertilization. Hum Reprod Update 8: 297-311, 2002.

EVANS JP, KOPF GS, SCHULTZ RM: Characterization of the binding of recombinant mouse sperm fertilin beta subunit to mouse eggs: evidence for adhesive activity via an egg beta1 integrin-mediated interaction. Dev Biol 187: 79-93, 1997.

FARD JAHROMI SS, SAMSIR MS: Construction and analysis of the cell surface's protein network for human spermegg interaction. ISRN Bioinformatics 2013: 1-8, 2013.

FRENETTE G, LESSARD C, MADORE E, FORTIER MA, SULLIVAN R: Aldose reductase and macrophage migration inhibitory factor are associated with epididymosomes and spermatozoa in the bovine epididymis. Biol Reprod 69: 1586-1592, 2003.

GIROUARD J, FRENETTE G, SULLIVAN R: Comparative proteome and lipid profiles of bovine epididymosomes collected in the intraluminal compartment of the caput and cauda epididymis. Int J Androl 34: 475-486, 2011.

GLAZAR AI, EVANS JP: Immunoglobulin superfamily member IgSF8 (EWI-2) and CD9 in fertilization: evidence of distinct functions for CD9 and a CD9-associated protein in mammalian sperm-egg interaction. Reprod Fertil Dev 21: 293-303, 2009.

GUPTA S, PRIMAKOFF P, MYLES DG: Can the presence of wild-type oocytes during insemination rescue the fusion defect of Cd9 null oocytes? Mol Reprod Dev 76: 602, 2009.

HALE G, RYE PD, WARFORD A, LAUDER I, BRITO-BABAPULLE A: The glycosylphosphatidylinositol-anchored lymphocyte antigen CDw52 is associated with the epididymal maturation of human spermatozoa. $J$ Reprod Immunol 23: 189-205, 1993.

HASEGAWA A, TAKENOBU T, KASUMI H, KOMORI S, KOYAMA K: CD52is synthetized in cumulus cells and secreted into cumular matrix during ovulation. Am J Reprod Immunol 60: 187-191, 2008

HE C, NONAKA M, TADA T, KOJI W, LI W, OKADA N, OKADA H: Decay accelerating factor in guinea-pig reproductive organs. Immunology 100: 91-98, 2000.

HEMLER ME: Integrin associated proteins. Curr Opin Cell Biol 10: 578-585, 1998.

HEMLER ME: Tetraspanin proteins mediate cellular penetration, invasion, and fusion evens and define a novel type of membrane microdomain. Annu Rev Cell Dev Biol 19: 397-422, 2003.

HIGGINGBOTTOM A, TAKAHASHI Y, BOLLING L, COONROD SA, WHITE JM, PARTRIDGE LJ, MONK PN: Structural requirements for the inhibitory action of the CD9 large extracellular domain in sperm/oocyte binding and fusion. Biochem Biophys Res Commun 311: 208-214, 2003.

HORVÁTH G, SERRU V, CLAY D, BILLARD M, BOUCHEIX C, RUBINSTEIN E: CD9 is linked to the integrinassociated tetraspans CD9, CD81, and CD82. J Biol Chem 273: 30537-30543, 1998.

INOUE N, IKAWA M, NAKANISHI T, MATSUMOTO M, NOMURA M, SEYA T, OKABE M: Disruption of mouse CD46 accelerated spontaneous acrosome reaction in sperm. Mol Cell Biol 23: 2614-2622, 2003.

INOUE N, YAMAGUCHI R, IKAWA M, OKABE M: Sperm-egg interaction and gene manipulated animals. Soc Reprod Fertil Suppl 65: 363-371, 2007.

ITO Y, YOSHIDA H, URUNO T, NAKANO K, TAKAMURA Y, MIYA A, KOBAYASHI K, YOKOZAWA T, MATSUZUKA F, KUMA K, MIYAUCHI A: KAI1 expression in thyroid neoplasms: its linkage with clinicopathologic features in papillary carcinoma. Pathol Res Pract 199: 79-83, 2003.

ITO C, YAMATOYA K, YOSHIDA K, MAEKAWA, MIYADO K, TOSHIMORI K: Tetraspanin family protein CD9 in the mouse sperm: unique localization, appearance, behavior and fate during fertilization. Cell Tissue Res 340: 583-594, 2010. 
JANKOWSKI SA, MITCHELL DS, SMITH SH, TRENT JM, MELTZER PS: SAS, a gene amplified in human sarcomas, encodes a new member of the transmembrane 4 superfamily of proteins. Oncogene 9: 1205-1211, 1994.

JÉGOU A, ZIYYAT A, BARRAUD-LANGE V, PEREZ E, WOLF JP, PINCET F, GOURIER C: CD9 tetraspanin generates fusion competent sites on the egg membrane for mammalian fertilization. Procl Natl Acad Sci USA 108: 10946-10951, 2011.

JONES PH, BISHOP LA, WATT FM: Functional significance of CD9 association with betal integrins in human epidermal keratinocytes. Cell Adhes Commun 4: 297-305, 1996.

KAEWMALA K, UDDIN MJ, CINAR MU, GROSSE-BRINKHAUS C, JONAS E, TESFAYE D, PHATSARA C, THOLEN E, LOOFT C, SCHELLANDER K: Association study and expression analysis of CD9 as candidate gene for boar sperm quality and fertility traits. Anim Reprod Sci 125: 170-179, 2011.

KAJI K, KUDO A: The mechanism of sperm-oocyte fusion in mammals. Reproduction 127: 423-429, 2004.

KAJI K, ODA S, SHIKANO T, OHNUKKI T, UEMATSU Y, SAKAGAMI J, TADA N, MIYAZAKI S, KUDO A: The gamete fusion process is defective in eggs of CD9-deficient mice. Nat Genet 24: 279-282, 2000.

KAJI K, ODA S, MIYAZAKI S, KUDO A: Infertility of CD9-deficient mouse eggs is reversed by mouse CD9, human CD9, or mouse CD81; polyadenylated mRNA injection developed for molecular analysis of sperm-egg fusion. Dev Biol 247: 327-334, 2002.

KANATSU-SHINOHARA M, TOYOKUNI S, SHINOHARA T: CD9 is a surface marker on mouse and rat male germline stem cells. Biol Reprod 70: 70-75, 2004.

KIERSZENBAUM AL, ROSSELOT C, RIVKIN E, TRES LL: Role of integrins, tetraspanins and ADAM proteins during the developing of apoptotic bodies by spermatogenic cells. Mol Reprod Dev 73: 906-917, 2006.

KLINOVSKA K, SEBKOVA N, DVORAKOVA-HORTOVA K: Sperm-egg fusion: a molecular enigma of mammalian reproduction. Int J Mol Sci 15: 10652-10668, 2014.

KOMOROWSKI S, SZCZEPANSKA K, MALESZEWSKI M: Distinct mechanisms underlie sperm-induced and protease-induced oolema block to sperm penetration. Int J Dev Biol 47: 65-69, 2003.

LAZO PA: Functional implications of tetraspanin proteins in cancer biology. Cancer Sci 98: 1666-1677, 2007.

LEFÉVRE B, WOLF JP, ZIYYAT A: Sperm-egg interaction: is there a link between tetraspanin(s) and GPI-anchored protein(s)? BioEssays 32: 143-152, 2010.

LE NAOUR F, RUBINSTEIN E, JASMIN C, PRENANT M, BOUCHEIX C: Severely reduced female fertility in CD9- deficient mice. Science 287: 319-321, 2000.

LI YH, HOU Y, MA W, YUAN JX, ZHANG D, SUN QY, WANG WH: Localization of CD9 in pig oocytes and its effects on sperm-egg interaction. Reproduction 127: 151-157, 2004.

LOFFLER S, LOTTSPEICH F, LANZA F, AZORSA DO, TER MEULEN V, SCHNEIDER-SCHAULIES J: CD9, a tetraspan transmembrane protein, renders cells susceptible to canine distemper virus. $J$ Virol 71: 42-49, 1997.

LOZAHIC S, CHRISTIANSEN D, MANIE S, GERLIER D, BILLARD M, BOUCHEIX C, RUBINSTEIN E: CD46 (membrane cofactor protein) associates with multiple betal integrins and tetraspans. Eur $J$ Immunol 30: 900-907, 2000.

MARTIN-ALONSO JM, HERNANDO N, GHOSH S, COCA-PRADOS M: Molecular cloning of the bovine CD9 antigen from ocular ciliary epithelial cells. J Biochem (Tokyo) 112: 63-67, 1992.

MICHALKOVÁ K, SIMON M, ANTALÍKOVÁ J, KLÍMA J, HOROVSKÁ L, JANKOVIČOVÁ J, HLUCHÝ S: Identification of bovine CD-52like molecule by monoclonal antibody IVA-543: distribution of CD-52like molecule in the bull genital tract. Theriogenology 74: 1066-1074, 2010.

MILLER BJ, GEORGES-LABOUESSE E, PRIMAKOFF P, MYLES DG: Normal fertilization occurs either eggs lacking the integrin $\alpha 6 \beta 1$ and is CD9-dependent. $J$ Cell Biol 149: 1289-1295, 2000.

MIYADO K, YAMADA G, YAMADA S, HASUWA H, NAKAMURA Y, RYU F, SUZUKI K, KOSAI K, INOUE K, OQURA A, OKABE M, MEKADA E: Requirement of CD9 on the egg plasma membrane for fertilization. Science 287: 321-324, 2000. 
MIYADO K, YOSHIDA K, YAMAGATA K, SAKAKIBARA K, OKABE M, WANG X, MIYAMOTO K, AKUTSU H, KONDO T, TAKAHASHI Y, BAN T, ITO C, TOSHIMORI K, NAKAMURA A, ITO M, MIYADO M, MEKADA E, UMEZAWA A: The fusing ability of sperm is bestowed by CD9-containing vesicles released from egg in mice. Procl Natl Sci 105: 12921-12926, 2008.

MIZUNO M, HARRIS CL, JOHNSON PM, MORGAN BP: Rat membrane cofactor protein (MCP; CD46) is expressed only in the acrosome of developing and mature spermatozoa and mediates binding to immobilized activated C3. Biol Reprod 71: 1374-1383, 2004.

OHNAMI N, NAKAMURA A, MIYADO M, SATO M, KAWANO N, YOSHIDA K, HARADA Y, TAKEZAWA Y, KANAI S, ONO C, TAKAHASHI Y, KIMURA KST, MIYADO K, UMEZAWA A: CD81 and CD9 work independently as extracellular components upon fusion of sperm and oocyte. Biol Open 1: 640-647, 2012.

OKABE M, ADACHI T, TAKADA K, ODA H, YAQASKI M, KOHAMA Y, MIMURA T: Capacitation-related changes in antigen distribution on mouse sperm heads and its relation to fertilization rate in vitro. $J$ Reprod Immunol 11: 91-100, 1987.

PARENT S, LEFIÈVRE L, BRINDLE Y, SULLIVAN R: Bull subfertility is associated with low levels of a sperm membrane antigen. Mol Reprod Dev 52: 57-65, 1999.

PARK KR, INOUE T, UEDA M, HIRANO T, HIGUCHI T, MAEDA M, KONISHI I, FUJIWARA H, FUJII S: CD9 is expressed on human endometrial epithelial cells in association with integrins $\alpha 6, \alpha 3$ and $\beta 1$. Mol Hum Reprod 6: $252-257,2000$.

ROONEY IA, MORGAN BP: Characterization of the membrane attack complement inhibitory protein CD59 antigen on human amniotic cells and in amniotic fluid. Immunology 76: 541-547, 1992.

ROONEY IA, DAVIES A, MORGAN BP: Membrane-attack complex (MAC)-mediated damage to spermatozoa: Protection of the cells by the presences on their membranes of MAC inhibitory proteins. Immunology 75: 499-506, 1992.

RUBINSTEIN E, BOUCHEIX C: Tetraspans. In: Guidebook to the Extracellular Matrix and Adhesion Proteins. KREIS T, VALE R (eds), Oxford University Press, Oxford, 1999, pp 321-324.

RUBINSTEIN E, LE NAOUR F, LAGAUDRIÈRE-GESBERT, BILLARD M, CONJEAUD H, BOUCHEIX C: CD9, CD63, CD81, and CD82 are components of a surface tetraspan network connected to HLA-DR and VLA integrins. Eur J Immunol 26: 2657-2665, 1996.

RUBINSTEIN E, ZIYYAT A, PRENANT M: Reduced fertility of female mice lacking CD81. Dev Biol 290: 351-358, 2006.

RUNGE KE, EVANS JE, HE ZY, GUPTA S, MCDONALD KL, STAHLBERG H, PRIMAKOFF P, MYLES DG: Oocyte CD9 is enriched on the microvillar membrane and required for normal microvillar shape and distribution. Dev Biol 304: 317-325, 2007.

SABETIAN S, SHAMSIR MS, NASER MA: Functional features and protein network of human sperm-egg interaction. Syst Biol Reprod Med 15: 1-9, 2014.

SALVOLINI E, BULDREGHINI E, LUCARINI G, VIGNINI A, LENZI A, DI PRIMIO R, BALERCIA G: Involvement of sperm plasma membrane and cytoskeletal proteins in human male infertility. Fertil Steril 99: 697-704, 2013

SCHWARZ MA, SCHALLER MD, GINSBERG MH: Integrins: emerging paradigms of signal transduction. Annu Rev Cell Dev Biol 11: 549-599, 1995.

SERRU V, LE NAOUR F, BILLARD M, AZORSA DO, LANZA F, BOUCHEIX C, RUBINSTEIN E: Selective tetraspan-integrin complexes (CD81/alpha4beta1, CD151/alpha3beta1, CD151/alpha6beta1) under conditions disrupting tetraspan interactions. Biochem J 340: 103-111, 1999.

SHAW S: Antibodies and molecules of the $5^{\text {th }}$ International Workshop of Leukocyte Differentiation Antigens. In: Leuckocyte Typing $V$ : White Cell Differentation Anigens. SCHLOSSMAN S, BOUMSELL L, GILKS L, GILKS W, HARLAN J, TEDDER T, TODD R (eds), Oxford University Press, Oxford, 1994.

SHAW ARE, DOMANSKA A, MAK A, GILCHRIST A, DOBLER K, VISSER L, POPPEMA S, FLIEGEL L, LETARTE M, WILLETT BJ: Ectopic expression of human and feline CD9 in a human B cell line confers $\beta 1$ integrin-dependent motility on fibronectin and laminin substrates and enhanced tyrosine phosphorylation. J Biol Chem 270: 24092-24099, 1995. 
SINCOCK PM, MAYRHOFER G, ASHMAN LK: Localisation of the transmembrane 4 superfamily (TM4SF) member PETA-6 (CD151) in normal human tissues: comparison with CD9, CD63 and alpha5beta1 integrin. J Histochem Cytochem 45: 515-525, 1997.

SINCOCK PM, FITTER S, PARTON RG, BERNDT MC, GAMBLE JR, ASHMAN LK: PETA-3/CD151, a member of the transmembrane 4 superfamily, is localized to the plasma membrane and endocytic system of endothelial cells, associates with multiple integrins and modulates cell function. J Cell Sci 112: 833-844, 1999.

STEIN KK, PRIMAKOFF P, MYLES D: Sperm-egg fusion: events at the plasma membrane. J Cell Sci 117: 6269-6274, 2004.

SULLIVAN R, FRENETTE G, GIROUARD J: Epididymosomes are involved in the acquisition of new sperm proteins during epididymal transit. Asian J Androl 9: 483-491, 2007.

SUTOVSKY P: Sperm-egg adhesion and fusion in mammals. Expert Rev Mol Med 1: e11, 2009.

SUTOVSKY P, NAVARA CS, SCHATTEN G: Fate of sperm mitochondria, and the incorporation, conversion, and disassembly of the sperm tail structures during bovine fertilization. Biol Reprod 55: 1195-1205, 1996.

SZALA S, KASAI Y, STEPLEWSKI Z, RODECK U, KOPROWSKI H, LINNENBACH AJ: Molecular cloning of cDNA for the human tumor-associated antigen CO-029 and identification of related transmembrane antigens. Proc Natl Acad Sci USA 87: 6833-6837, 1990.

TAKAGI S, FUJIKAWA K, IMAI T, FUKUHARA N, FUKUDOME K, MINEGISHI M, TSUCHIYA S, KONNO T, HINUMA Y, YOSHIE O: Identification of a highly specific surface marker of T-cell acute lymphoblastic leukemia and neuroblastoma as a new member of the transmembrane 4 superfamily. Int J Cancer 61: 706-715, 1995.

TAKAHASHI Y, BIGLER D, ITO Y, WHITE JM: Sequence-specific interaction between the disintegrin domain of mouse ADAM3 and murine eggs: role of $\beta 1$ integrin-associated proteins CD9, CD81 and CD98. Mol Biol Cell 12: 809-820, 2001.

TAYLOR CT, JOHNSON PM: Complement-binding proteins are strongly expressed by human preimplantation blastocyst and cumulus cells as well as gametes. Mol Hum Reprod 2: 52-59, 1996.

THERY C, OSTROWSKI M, SEGURA E: Membrane vesicles as conveyors of immune responses. Nat Rev Immunol $\mathbf{9}$ 581-593, 2009.

TRAJKOVIC K, HSU C, CHIANTIA S, RAJENDRAN L, WENZEL D, WIENLAND F, SCHWILLE P, BRÜGGER B, SIMONS M: Ceramide triggers budding of exosome vesicles into multivesicular endosomes. Science 319: 1244-1247, 2008.

VICENS A, ROLDAN ERS: Coevolution of positively selected IZUMO1 and CD9 in rodents: Evidence of interaction between gamete fusion proteins? Biol Reprod 90: 1-9, 2014.

WANG WH, SUN QY, HOSOE M, SHIOYA Y, DAY BN: Quantified analysis of cortical granule distribution and exocytosis of porcine oocytes during meiotic maturation and activation. Biol Reprod 56: 1376-1382, 1997.

WUBBOLTS R, LECKIE RS, VEENHUIZEN PT, SCHWARZMANN G, MŐBIUS W, HOERNSCHEMEYER J, SLOT JW, GEUZE HJ, STOORVOGEL W: Proteomic and biochemical analyses of human B cell-derived exosomes. Potential implications for their function and multivesicular body formation. J Biol Chem 278: 10963-10972, 2003.

XIANG W, MACLAREN LA: Expression of fertilin and CD9 in bovine trophoblast and endometrium during implantation. Biol Reprod 66: 1790-1796, 2002.

XU C, MAO D, HOLERS VM, PALANCA B, CHENG AM, MOLINA H: A critical role for murine complement regulator crry in fetomaternal tolerance. Science 21: 498-501, 2000.

YANEZ-MO M, TEJEDOR R, ROUSELLE P, SANCHEZ-MADRID F: Tetraspanins in intercellular adhesion of polarized epithelial cells: spatial and functional relationship to integrins and cadherins. J Cell Sci 144: 577-587, 2001.

YANG X, CLAAS C, KRAEFT SK, CHEN LB, WANG Z, KREIDBERG JA, HEMLER ME: Palmitoylation of tetraspanin proteins: modulation of CD151 interactions, subcellular distribution, and integrin-dependent cell morphology. Mol Biol Cell 13: 767-781, 2002. 
YAUCH RL, BERDITCHEVSKI F, HARLER MB, REICHNER J, HEMLER ME: Highly stoichiometric, stable, and specific association of integrin alpha3beta1 with CD151 provides a major link to phosphatidylinositol-4 kinase and may regulate cell migration. Mol Biol Cell 9: 2751-2765, 1998.

YAUCH RL, KAZAROV AR, DESAI B, LEE RT, HEMLER ME: Direct extracellular contact between integrin alpha(3)beta(1) and TM4SF protein CD151. J Biol Chem 275: 9230-9238, 2000.

YUAN R, PRIMAKOFF P, MYLES DG: A role for the disintegrin domain of cyritestin, a sperm surface protein belonging to the ADAM family, in mouse sperm-egg plasma membrane adhesion and fusion. J Cell Biol 137: 135-112, 1997.

YUNTA M, LAZO PA: Tetraspanin proteins as organisers of membrane microdomains and signalling complexes. Cell Signal 15: 559-564, 2003.

ZHOU GB, LIU GS, MENG QG, LIU Y, HOU YP, WANG XX, LI N, ZHU SE: Tetraspanin CD9 in bovine oocytes and its role in fertilization. $J$ Reprod Dev 55: 305-308, 2009.

ZHU GZ, MILLER BJ, BOUCHEIX C, RUBINSTEIN C, LIU CC, HYNES RO, MYLES DG, PRIMAKOFF P: Residues SFQ (173-175) in the large extracellular loop of CD9 are required for gamete fusion. Development 129: 1995-2002, 2002.

ZIYYAT A, RUBINSTEIN E, MONIER-GAVELLE F, BARRAUD V, KULSKI O, PRENANT M, BOUCHEIX C, BOMSEL M, WOLF JP: CD9 controls the formation of clusters that contain tetraspanins and the integrin $\alpha 6 \beta 1$, which are involved in human and mouse gamete fusion. J Cell Sci 119: 416-424, 2006.

ZUCCOTTI M, YANAGIMACI R, YANAGIMACHI H: The ability of hamster oolema to fuse with spermatozoa: its acquisition during oogenesis and loss after fertilization. Development 112: 143-152, 1991. 